\title{
Women's experiences of participating in a randomised trial comparing alternative policies for timing of cord clamping at very preterm birth: a questionnaire study
}

Lucy Bradshaw $^{1}$ (D) Alexandra Sawyer ${ }^{2}$, Eleanor Mitchell ${ }^{1}$, Lindsay Armstrong-Buisseret ${ }^{1}$, Susan Ayers ${ }^{3}$ and Lelia Duley ${ }^{1 *}$

\begin{abstract}
Background: The Cord Pilot Trial compared two alternative policies for cord-clamping at very preterm birth at eight UK tertiary maternity units: clamping after at least 2 min and immediate neonatal care with cord intact, or clamping within $20 \mathrm{~s}$ and neonatal care after clamping. This paper reports views and experiences of the women who participated in the trial (261 randomised), based on data from two self-completed questionnaires.

Methods: Women were given or posted the first questionnaire between 4 and 8 weeks after birth, and posted a second similar questionnaire at 1 year. Both questionnaires included three questions about experiences of participating in the trial: (1) If time suddenly went backwards and you had to do it all over again, would you agree to participate in the Cord Pilot Trial?; (2) Please tell us if there was anything about the Cord Pilot Trial that you think could have been done better; and (3) Please tell us if there was anything about the Cord Pilot Trial, or your experiences of joining the trial, that you think were particularly good.

Results: One hundred and eighty-six women completed the first questionnaire and 133 completed the second. At both time points, $90 \%$ responded 'probably' or 'definitely' to participating in the trial again. More women randomised to deferred clamping responded 'definitely yes' than those allocated immediate clamping (78\% versus $67 \%$ first questionnaire). Women were positive about the level of information and explanations, the friendly and caring staff, and the benefits for their baby and others as a result of participating in the trial. Suggestions for how the trial could be done better included being approached earlier, better staff communication about the trial, more information overall, and better timing of follow-up.
\end{abstract}

Conclusions: Women were largely positive about participating in the trial. Nevertheless, they had suggestions for how the study could have been improved. These suggestions have implications for the design of future trials.

Trial registration: ISRCTN21456601. Registered on 28 February 2013.

Keywords: Preterm birth, Umbilical cord-clamping, Neonatal care with cord intact, Experience, Clinical trials

\footnotetext{
*Correspondence: Lelia.Duley@nottingham.ac.uk

${ }^{1}$ Nottingham Clinical Trials Unit, University of Nottingham, Nottingham NG7

2UH, UK

Full list of author information is available at the end of the article
}

(C) The Author(s). 2019 Open Access This article is distributed under the terms of the Creative Commons Attribution 4.0 International License (http://creativecommons.org/licenses/by/4.0/), which permits unrestricted use, distribution, and reproduction in any medium, provided you give appropriate credit to the original author(s) and the source, provide a link to the Creative Commons license, and indicate if changes were made. The Creative Commons Public Domain Dedication waiver (http://creativecommons.org/publicdomain/zero/1.0/) applies to the data made available in this article, unless otherwise stated. 


\section{Background}

The Cord Pilot Trial was a randomised comparison of alternative policies for the timing of cord-clamping at very preterm birth [1-3] at eight UK tertiary maternity units. The trial included two novel elements which may have influenced women's experiences of participation. First, to allow deferred cord-clamping without delaying neonatal care for babies requiring resuscitation at birth, newborn life support at birth was provided with cord intact and thus also allowed women to share the first moments of their baby's life $[4,5]$. Second, so that high-risk women and babies could be offered the opportunity to participate, we developed a two-stage consent pathway (with oral assent before the birth and written consent after the birth) for use when birth was imminent $[6,7]$; this pathway was used for almost one third of recruitment [3].

Randomised trials are the 'gold standard' for evaluation of healthcare interventions. Understanding the experiences of women recruited to trials during pregnancy is especially important as they are also making a decision on behalf of their unborn child [8]. Conducting trials in stressful circumstances, such as when birth is likely to be very preterm, is challenging. This is particularly so when time for offering participation is limited; for example, when birth is imminent [9]. Better understanding of women's experiences may help improve the design of trials and their relevance to the participants, thereby minimising potential barriers to participation, improving the experience of participating and improving recruitment and retention.

This paper reports the views and experiences of women about participating in the Cord Pilot Trial, based on self-completed questionnaires up to 1 year after the birth.

\section{Methods}

The Cord Pilot Trial compared cord-clamping after at least $2 \mathrm{~min}$ and providing immediate neonatal care, if needed, with cord intact (deferred clamping) with clamping within $20 \mathrm{~s}$ and neonatal care after clamping (immediate clamping) at very preterm birth $(<32$ weeks gestation) $[1,2]$. Initially, the objective was to assess the feasibility of conducting a large, multicentre, UK trial and, as feasibility was demonstrated, recruitment continued whilst funding for the full trial was sought. The trial closed when the funding application was unsuccessful [10]. Throughout the planning and conduct of the trial, we worked with the National Childbirth Trust and Bliss (a UK-based charity for babies born prematurely or sick) for a strong parent perspective.

Posters about the study and summary information sheets were available in antenatal clinics and on antenatal wards. Women at risk of very preterm birth were invited to participate; if they accepted they gave written consent. Eligibility and willingness to participate were checked before randomisation, which was during labour or at caesarean section. If birth was imminent and the attending clinician felt it appropriate, women were offered a brief description of the trial and offered participation (oral assent). Those who gave oral assent were then randomised. After the birth, these women had an opportunity to discuss the study in more detail, and were invited to give written consent for participation in follow-up. This two-stage consent pathway was developed in discussion with the National Childbirth Trust and Bliss, to be used only when there was insufficient time for the usual consent process, giving these women the opportunity to participate [1].

For follow-up, women were asked to complete two similar questionnaires, the first between 4 and 8 weeks after giving birth, the second at 1 year. We initially planned that the first questionnaire would be posted to the woman's home 6 weeks after the birth, but this often coincided with discharge of the baby which was not a good time for the women to receive it. Therefore, we changed this and if the baby was still in hospital at age 4 weeks, the research midwife/nurse gave the questionnaire to the woman when she was visiting. If the baby was not in hospital at 4 weeks, we posted it to her 8 weeks after the birth. If the baby died or was stillborn, covering letters and the questionnaires were adapted appropriately. Before sending the questionnaire at 1 year, we checked the baby's status with the recruiting site, or with the general practitioner if the family had not been seen recently at the site. We then posted the questionnaire, along with a birthday card for the child (if appropriate). A stamped addressed envelope was provided to return completed questionnaires. If there was no response, we sent a postal reminder after 2 weeks. If there was still no response after another 2 weeks, we telephoned the woman and offered the opportunity to complete the questionnaire over the telephone. If no telephone number was available, we sent a second postal reminder.

Both questionnaires included three questions about the women's experience of participating in the trial, which had been previously used for a trial involving women with pre-eclampsia [11]:

1. If time suddenly went backwards and you had to do it all over again, would you agree to participate in the Cord Pilot Trial? (response options: 'definitely yes,' 'probably yes,', not sure,' 'probably no', and 'definitely no'. Free text to explain response)

2. Please tell us if there was anything about the Cord Pilot Trial that you think could have been done better (free-text response) 
3. Please tell us if there was anything about the Cord Pilot Trial, or your experience of joining the trial, that you think was particularly good (free-text response)

Responses to other questions about symptoms of anxiety or depression, satisfaction with care at birth, and breastfeeding/expressing are reported elsewhere [12].

\section{Data analysis}

For the analysis of outcomes to discharge, women who gave birth after $35^{+6}$ weeks gestation were excluded as outcomes for these babies are different from those born very preterm [3]. These women are, therefore, also excluded here. The number of questionnaires returned was described, along with the proportion of women completing each of the three questions about participation. We pre-specified factors that might influence women's experiences [1], with primary variables being death of the baby and the allocated group. Secondary variables were maternal age at recruitment, gestation at recruitment less than 30 weeks, whether the two-stage consent pathway was used, severe postpartum haemorrhage (blood loss $>1000 \mathrm{ml}$ ), possible depression (Hospital Anxiety and Depression Scale depression score $\geq 8$ [13]), length of stay in neonatal intensive care unit longer than 6 weeks, and need for a reminder to complete the questionnaire. Responses about whether women would participate again were tabulated overall and according to these pre-specified variables for the two questionnaires.

We coded the free-text responses and grouped responses within themes using inductive content analysis, which involved the following steps: (1) all responses were read twice for each question; (2) line-by-line analysis summarising the content of each statement; (3) a coding scheme based on the content of women's responses was created; and (4) responses were then coded using the coding scheme. For Question 1, respondents were asked to explain why they had chosen a particular response category; therefore, these free-text responses were grouped according to the fixed-response category that they were linked to. The number with comments within each theme are presented according to allocated group and consent pathway (usual one-stage or two-stage). We collated and analysed responses using Microsoft Excel which is a useful tool for grouping open-ended responses into categories that can be summarised qualitatively and quantitatively [14].

\section{Results}

Overall, 261 women were randomised between March 2013 and February 2015, six of whom were excluded as they gave birth after $35^{+6}$ weeks and one withdrew the use of their data, leaving 254 women for the analysis of outcome at hospital discharge (Fig. 1) [3]. A further six women were excluded from follow-up after discharge: three for whom we had oral assent only and so consent for follow-up was not available, and three whose baby died before discharge and the site advised us not to contact them. Four women were sent the 1-year questionnaire only, as their baby died and the site advised us not to send the first questionnaire.

Of 244 women sent the first questionnaire, four did not complete it and asked not to be contacted again, another completed it but asked for no further follow-up. Overall, 186 of the first questionnaires (76\%) were returned $(79 \%$ deferred clamping, $74 \%$ immediate clamping) (Fig. 1). For one woman the site advised us not to send the second questionnaire due to safeguarding issues. Two hundred and forty-two women were sent the second questionnaire at 1 year, and 133 (55\%) responded (66\% deferred clamping, $43 \%$ immediate clamping). Although the questionnaires asked about the women, a few were completed by someone else on their behalf (six of the first questionnaires and five of the second). For six of the first questionnaires and three of the second, it was not stated who completed the questionnaire.

For both questionnaires, characteristics at trial entry for the women who responded were similar between the allocated groups (Table 1). A higher proportion of women allocated deferred clamping responded than those allocated immediate clamping, and this was more marked for the second questionnaire at 1 year. Factors in response were similar in both groups and have been described in detail elsewhere: response was higher for women aged 30 years or older at the time that they gave consent, and for those recruited during their first pregnancy lasting 20 weeks or more [12]. Response for the first questionnaire was similar, although slightly lower, for women recruited using the two-stage consent pathway (69\%) and the usual one-stage consent pathway (78\%). Response for the second questionnaire was very similar for the two consent pathways (56\% for usual one-stage and $53 \%$ for two-stage).

\section{'If time suddenly went backwards, and you had to do it all over again, would you agree to participate in the Cord Pilot Trial?'}

Overall, responses to this question were positive, with more than $90 \%$ of respondents saying 'probably yes' or 'definitely yes' on both questionnaires (Table 2). Responses were similar for women recruited during the feasibility phase, and during the extended recruitment phase. However, for both questionnaires more women allocated deferred clamping responded 'definitely yes' than those allocated immediate clamping ( $78 \%$ versus $67 \%$ on the first questionnaire, $84 \%$ versus $69 \%$ on the second) (Table 2). Of 113 women who completed this question 


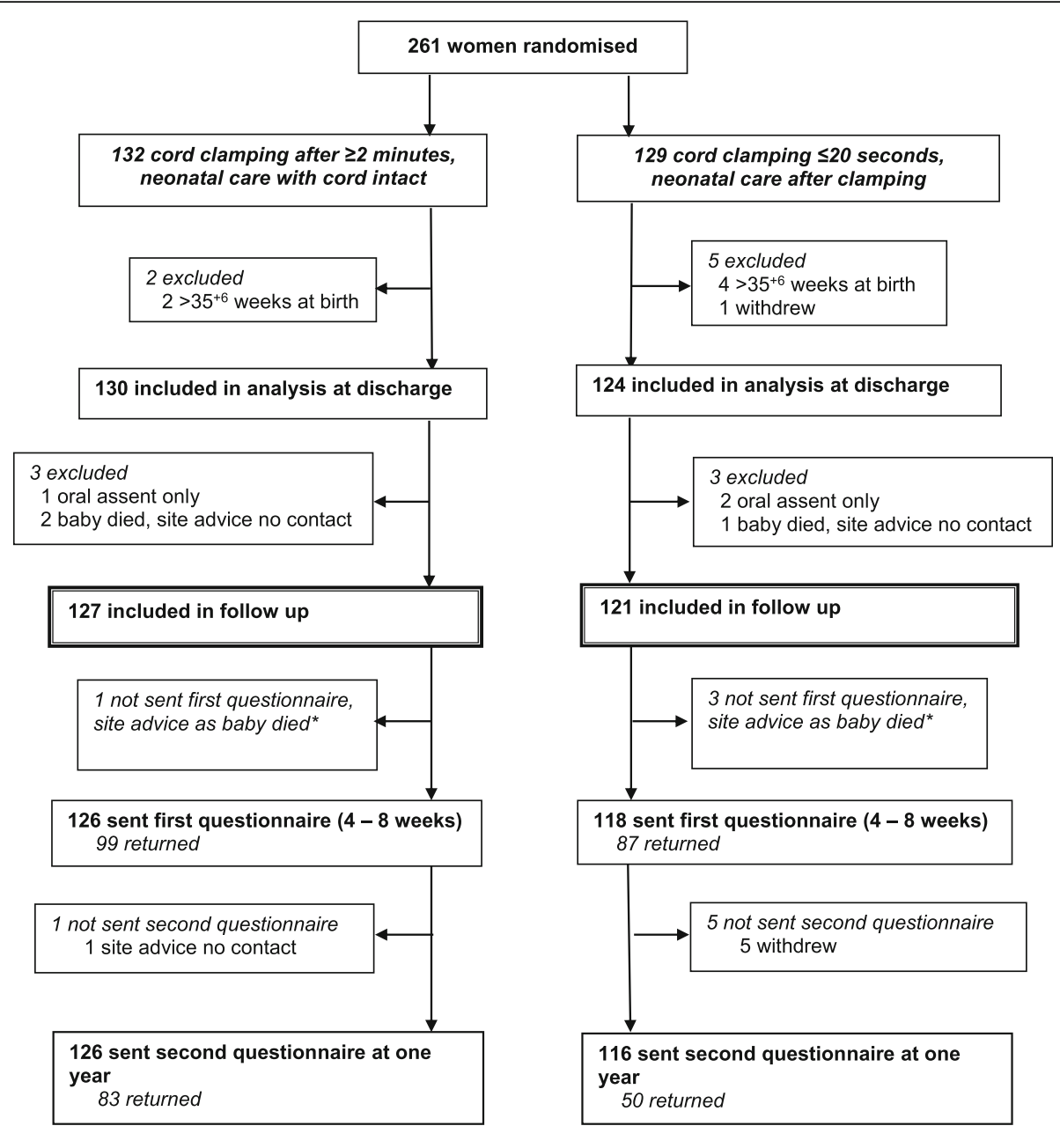

* women were sent the one year questionnaire

Fig. 1 Consolidated Standards of Reporting Trials (CONSORT) flow for the follow-up of women to 1 year with questionnaires

on both questionnaires, 81 (71\%) responded 'definitely yes' on both. There were no clear differences according to any pre-specified factors, including the consent pathway (Table 2).

Of those who provided free-text explaining their responses, on the first questionnaires the main reasons for responding 'definitely yes' were that research is important $(n=34)$, benefits to the baby $(n=26)$, benefits to others $(n=26)$, and no risk to the baby $(n=22)$ (see Additional file 1: Table S1). Another relatively common reason was that women thought the trial was important and/or were positive about deferred cord-clamping $(n=12)$. For example, some women had already planned for deferred cord-clamping if their pregnancy went to term. Some women reported that being in the trial was a positive experience $(n=10)$ and others mentioned the comfort in seeing their baby being cared for beside them $(n=3)$. Reasons for responses of 'probably yes' were similar. One respondent selected 'probably no', and said this was because she thought the trial had no impact (positive or negative). Two women responded 'definitely no'; for one this was because of disappointment with the allocated group, the other had a strong preference for one intervention. One of these respondents also felt hounded by trial staff.

For the second questionnaire at 1 year, women's reasons for responding 'definitely yes' were similar: benefit to others $(n=35)$, the importance of research $(n=23)$, benefit to the baby $(n=22)$, and no risk to the baby $(n=10)$. They also said that the trial not having any impact on them and/or the birth experience was a factor. The two women who selected 'probably no' explained that this was because once their baby was born the trial felt less like a priority. No reason was given for the single response of 'definitely no' (see Additional file 1: Table S2).

The first questionnaire was completed by five women whose baby had died and the second questionnaire at 1 year by four women. Women whose baby died responded 
Table 1 For women who returned questionnaires: baseline characteristics, baby's length of stay and baby status

\begin{tabular}{|c|c|c|c|c|}
\hline & \multicolumn{2}{|l|}{ First (at 4-8 weeks) } & \multicolumn{2}{|l|}{ Second (at 1 year) } \\
\hline & $\begin{array}{l}\text { Clamp } \geq 2 \text { min + neonatal } \\
\text { care with cord intact }\end{array}$ & $\begin{array}{l}\text { Clamp } \leq 20 s+\text { neonatal } \\
\text { care after clamping }\end{array}$ & $\begin{array}{l}\text { Clamp } \geq 2 \min +\text { neonatal } \\
\text { care with cord intact }\end{array}$ & $\begin{array}{l}\text { Clamp } \leq 20 s+\text { neonatal } \\
\text { care after clamping }\end{array}$ \\
\hline & $n=99(\%)$ & $n=87(\%)$ & $n=83(\%)$ & $n=50(\%)$ \\
\hline \multicolumn{5}{|l|}{ Age (years) } \\
\hline$<20$ & $2(2 \%)$ & $7(8 \%)$ & $1(1 \%)$ & $1(2 \%)$ \\
\hline $20-24$ & $14(14 \%)$ & $14(16 \%)$ & $11(13 \%)$ & $6(12 \%)$ \\
\hline $25-29$ & 19 (19\%) & $21(24 \%)$ & $13(16 \%)$ & $12(24 \%)$ \\
\hline $30-34$ & $41(41 \%)$ & $29(33 \%)$ & $38(46 \%)$ & $16(32 \%)$ \\
\hline $35-39$ & $18(18 \%)$ & $10(11 \%)$ & $15(18 \%)$ & $9(18 \%)$ \\
\hline$\geq 40$ & $5(5 \%)$ & $6(7 \%)$ & $5(6 \%)$ & $6(12 \%)$ \\
\hline \multicolumn{5}{|l|}{ Consent pathway } \\
\hline usual one-stage & $73(74 \%)$ & $68(78 \%)$ & $60(72 \%)$ & $39(78 \%)$ \\
\hline two-stage & $26(26 \%)$ & $19(22 \%)$ & $23(28 \%)$ & $11(22 \%)$ \\
\hline \multicolumn{5}{|l|}{ Gestation at birth (weeks) } \\
\hline$<26$ & $15(15 \%)$ & $8(9 \%)$ & $12(14 \%)$ & $4(8 \%)$ \\
\hline $26^{+0}-27^{+6}$ & $22(22 \%)$ & $16(18 \%)$ & $16(19 \%)$ & $8(16 \%)$ \\
\hline $28^{+0}-29^{+6}$ & $27(27 \%)$ & $34(39 \%)$ & $22(27 \%)$ & $20(40 \%)$ \\
\hline $30^{+0}-31^{+6}$ & $34(34 \%)$ & $28(32 \%)$ & $31(37 \%)$ & $16(32 \%)$ \\
\hline$\geq 32$ & $1(1 \%)$ & $1(1 \%)$ & $2(2 \%)$ & $2(4 \%)$ \\
\hline \multicolumn{5}{|l|}{ Blood loss at birth (ml) } \\
\hline $0-499$ & 49 (49\%) & $44(51 \%)$ & $41(49 \%)$ & $23(46 \%)$ \\
\hline 500-999 & 41 (41\%) & $33(38 \%)$ & $34(41 \%)$ & $21(42 \%)$ \\
\hline$\geq 1000$ & $9(9 \%)$ & $10(11 \%)$ & $8(10 \%)$ & $6(12 \%)$ \\
\hline \multicolumn{5}{|l|}{ For baby: } \\
\hline \multicolumn{5}{|l|}{$\begin{array}{l}\text { length of hospital stay } \\
\text { (weeks) }\end{array}$} \\
\hline$\leq 6$ & $27(27 \%)$ & $24(28 \%)$ & $25(30 \%)$ & $16(32 \%)$ \\
\hline$>6$ & $70(71 \%)$ & $61(70 \%)$ & $56(67 \%)$ & $33(66 \%)$ \\
\hline died before discharge & $2(2 \%)$ & $2(2 \%)$ & $2(2 \%)$ & $1(2 \%)$ \\
\hline \multicolumn{5}{|l|}{$\begin{array}{l}\text { status when questionnaire } \\
\text { completed }^{2}\end{array}$} \\
\hline alive & 98 (99\%) & 83 (95\%) & $81(98 \%)$ & $48(96 \%)$ \\
\hline dead & $1(1 \%)$ & $4(5 \%)$ & $2(2 \%)$ & $2(4 \%)$ \\
\hline
\end{tabular}

1 - For twin births, category is based on longest stay. If one twin died, category is based on stay of surviving twin, this occurred for two families completing the postnatal questionnaire and one family completing the 1-year questionnaire

2 - For twin births, if one twin died status is reported according to the deceased twin. Note, for one participant the first questionnaire was completed when the baby was still in hospital who later died. Number of babies who died includes stillbirths

either 'not sure,' probably yes' or 'definitely yes' to whether they would participate in the trial again (Table 2). The small number of responses from women whose baby died did not allow qualitative differences in responses to the three open-ended questions between bereaved and non-bereaved parents to be explored.

‘Please tell us if there was anything about the Cord Pilot Trial that you think could have been done better' Of women completing the first questionnaire, two thirds $(125 / 186,67 \%)$ responded to this question (67 deferred clamping, 58 immediate clamping); of whom three quarters (93/125, 74\%) said that they did not think that anything could have been done better. Of the 32 who suggested that things that could have been done better, the main themes were: to approach women earlier or at a different time to join the trial $(n=9)$; to explain afterwards which intervention they received $(n=4)$; better staff communication about the trial $(n=3)$; and provide more information $(n=3)$ (Table 3$)$. Many of the women who gave suggestions for how the trial could have been done better responded either 'definitely yes' $(n=23)$ or 'probably yes' $(n=4)$ to Question 1. 
Table 2 Response to Question 1, overall and according to factors that might influence experience

\begin{tabular}{|c|c|c|c|c|c|c|c|c|c|c|}
\hline & \multicolumn{10}{|c|}{$\begin{array}{l}\text { 'If time suddenly went backwards, and you had to do it all over again, would you agree to participate in the Cord Pilot } \\
\text { Trial?' }\end{array}$} \\
\hline & \multicolumn{5}{|c|}{ First (at 4-8 weeks) } & \multicolumn{5}{|c|}{ Second (at 1 year) } \\
\hline & $\begin{array}{l}\text { Definitely } \\
\text { no }\end{array}$ & $\begin{array}{l}\text { Probably } \\
\text { no }\end{array}$ & $\begin{array}{l}\text { Not } \\
\text { sure }\end{array}$ & $\begin{array}{l}\text { Probably } \\
\text { yes }\end{array}$ & $\begin{array}{l}\text { Definitely } \\
\text { yes }\end{array}$ & $\begin{array}{l}\text { Definitely } \\
\text { no }\end{array}$ & $\begin{array}{l}\text { Probably } \\
\text { no }\end{array}$ & $\begin{array}{l}\text { Not } \\
\text { sure }\end{array}$ & $\begin{array}{l}\text { Probably } \\
\text { yes }\end{array}$ & $\begin{array}{l}\text { Definitely } \\
\text { yes }\end{array}$ \\
\hline Total & $2(1 \%)$ & $1(1 \%)$ & $9(5 \%)$ & $36(20 \%)$ & $131(73 \%)$ & $1(1 \%)$ & $2(2 \%)$ & $6(5 \%)$ & $19(15 \%)$ & $103(79 \%)$ \\
\hline $\begin{array}{l}\text { Clamping after } \geq 2 \mathrm{~min}+\text { neonatal } \\
\text { care with cord intact }\end{array}$ & $1(1 \%)$ & - & $3(3 \%)$ & $17(18 \%)$ & 75 (78\%) & - & $1(1 \%)$ & $1(1 \%)$ & $11(13 \%)$ & $69(84 \%)$ \\
\hline $\begin{array}{l}\text { Clamping } \leq 20 s+\text { neonatal care } \\
\text { after clamping }\end{array}$ & $1(1 \%)$ & $1(1 \%)$ & $6(7 \%)$ & $19(23 \%)$ & $56(67 \%)$ & $1(2 \%)$ & $1(2 \%)$ & $5(10 \%)$ & $8(16 \%)$ & $34(69 \%)$ \\
\hline Gestation at birth (weeks) $<26$ & - & $1(4 \%)$ & $1(4 \%)$ & $3(13 \%)$ & $18(78 \%)$ & - & - & $1(7 \%)$ & $3(20 \%)$ & $11(73 \%)$ \\
\hline $26^{+0}-27^{+6}$ & - & - & $2(5 \%)$ & $8(22 \%)$ & $27(73 \%)$ & - & $1(4 \%)$ & - & $2(9 \%)$ & $20(87 \%)$ \\
\hline $28^{+0}-29^{+6}$ & $1(2 \%)$ & - & $2(3 \%)$ & 17 (29\%) & $39(66 \%)$ & $1(2 \%)$ & - & $1(2 \%)$ & $9(21 \%)$ & 31 (74\%) \\
\hline $30^{+0}-31^{+6}$ & $1(2 \%)$ & - & $4(7 \%)$ & $8(14 \%)$ & $45(78 \%)$ & - & $1(2 \%)$ & $3(6 \%)$ & $5(11 \%)$ & 38 (81\%) \\
\hline$\geq 32$ & - & - & - & - & $2(100 \%)$ & - & - & $1(25 \%)$ & - & $3(75 \%)$ \\
\hline \multicolumn{11}{|l|}{ Consent pathway } \\
\hline usual one-stage & $2(1 \%)$ & $1(1 \%)$ & $6(4 \%)$ & $28(21 \%)$ & 99 (73\%) & $1(1 \%)$ & $2(2 \%)$ & $6(6 \%)$ & $8(8 \%)$ & 81 (83\%) \\
\hline two-stage & - & - & $3(7 \%)$ & $8(19 \%)$ & $32(74 \%)$ & - & - & - & $11(33 \%)$ & $22(67 \%)$ \\
\hline Age at trial entry (years) $<20$ & - & - & $1(11 \%)$ & $3(33 \%)$ & $5(56 \%)$ & - & - & $1(50 \%)$ & - & $1(50 \%)$ \\
\hline $20-24$ & - & - & $1(4 \%)$ & $5(19 \%)$ & $20(77 \%)$ & - & - & $1(6 \%)$ & $4(24 \%)$ & $12(71 \%)$ \\
\hline $25-29$ & - & $1(3 \%)$ & $2(5 \%)$ & $4(11 \%)$ & $31(82 \%)$ & - & $1(4 \%)$ & $2(8 \%)$ & $1(4 \%)$ & $21(84 \%)$ \\
\hline $30-34$ & $2(3 \%)$ & - & $4(6 \%)$ & 15 (22\%) & $47(69 \%)$ & - & $1(2 \%)$ & $1(2 \%)$ & $8(15 \%)$ & $43(81 \%)$ \\
\hline $35-39$ & - & - & - & $7(26 \%)$ & $20(74 \%)$ & - & - & - & $5(22 \%)$ & $18(78 \%)$ \\
\hline$\geq 40$ & - & - & $1(9 \%)$ & $2(18 \%)$ & $8(73 \%)$ & $1(9 \%)$ & - & $1(9 \%)$ & $1(9 \%)$ & $8(73 \%)$ \\
\hline Blood loss at birth (ml) 0-499 & $1(1 \%)$ & $1(1 \%)$ & $4(4 \%)$ & $18(20 \%)$ & $65(73 \%)$ & - & - & $5(8 \%)$ & $10(16 \%)$ & $48(76 \%)$ \\
\hline $500-999$ & - & - & $4(6 \%)$ & $16(23 \%)$ & $51(72 \%)$ & - & $2(4 \%)$ & $1(2 \%)$ & $7(13 \%)$ & $44(81 \%)$ \\
\hline$\geq 1000$ & $1(5 \%)$ & - & $1(5 \%)$ & $2(11 \%)$ & $15(79 \%)$ & $1(7 \%)$ & - & - & $2(14 \%)$ & $11(79 \%)$ \\
\hline For baby, length of stay $>6$ weeks & $1(1 \%)$ & $1(1 \%)$ & $4(3 \%)$ & $27(21 \%)$ & $95(74 \%)$ & $1(1 \%)$ & $1(1 \%)$ & $3(3 \%)$ & $13(15 \%)$ & $69(79 \%)$ \\
\hline $\begin{array}{l}\text { Hospital Anxiety and Depression } \\
\text { Scale depression score } \geq 8\end{array}$ & $1(2 \%)$ & - & $6(12 \%)$ & $9(17 \%)$ & $36(69 \%)$ & - & - & - & $5(20 \%)$ & $20(80 \%)$ \\
\hline $\begin{array}{l}\text { Baby died before questionnaire } \\
\text { completed (including stillbirths) }\end{array}$ & - & - & $1(25 \%)$ & $1(25 \%)$ & $2(50 \%)$ & - & - & - & $1(25 \%)$ & $3(75 \%)$ \\
\hline $\begin{array}{l}\text { Questionnaire completed after } \\
\text { reminder }\end{array}$ & $2(2 \%)$ & - & $3(4 \%)$ & $17(21 \%)$ & $59(73 \%)$ & $1(1 \%)$ & $1(1 \%)$ & $6(7 \%)$ & $14(17 \%)$ & $60(73 \%)$ \\
\hline \multicolumn{11}{|l|}{ Recruited period } \\
\hline First year (feasibility phase) & $1(1 \%)$ & - & $4(5 \%)$ & 19 (22\%) & $62(72 \%)$ & - & $1(1 \%)$ & $5(7 \%)$ & $10(14 \%)$ & $54(77 \%)$ \\
\hline Second year & $1(1 \%)$ & $1(1 \%)$ & $5(5 \%)$ & $17(18 \%)$ & $69(74 \%)$ & $1(2 \%)$ & $1(2 \%)$ & $1(2 \%)$ & $9(15 \%)$ & 49 (80\%) \\
\hline
\end{tabular}

Note:

- 7 of the 186 participants returning the first questionnaire did not complete this question including one of the participants whose baby died ( 3 in the clamp cord after at least 2 min group and 4 in the clamp cord within $20 \mathrm{~s}$ group)

- 2 of the 132 participants returning the second questionnaire at 1 year did not complete this question ( 1 in each group)

For the second questionnaire at 1 year, a similar proportion responded to this question $(85 / 133,64 \%)$ (51 deferred clamping, 34 immediate clamping); of whom a similar proportion $(61 / 85,72 \%)$ said that they did not think anything could have been done better. Three women found it difficult to suggest what could have been done better: 'I don't have anything similar to compare Cord Trial with'. Of the 24 who made suggestions about what could be done better, these were similar to those on the first questionnaire but with the addition of a few comments about the follow-up: to approach women earlier or at a different time to join the trial $(n=6)$; to provide more updates and information about the trial $(n=5)$; better timing of the first questionnaire follow-up $(n=3)$; and decide earlier about which arm of the trial a woman was allocated to $(n=2)$ (Additional file 2). Many of the women who gave suggestions for how the trial could have been done better responded either 'definitely yes' $(n=16)$ or 'probably yes' $(n=6)$ to Question 1. 
Table 3 For the first questionnaire, summary of responses about what could have been done better

\begin{tabular}{|c|c|c|c|c|c|}
\hline & \multicolumn{2}{|c|}{$\begin{array}{l}\text { Consent } \\
\text { pathway }\end{array}$} & \multicolumn{2}{|c|}{ Allocated group } & \multirow[t]{2}{*}{ Sample of comments } \\
\hline & $\begin{array}{l}\text { Usual } \\
\text { one- } \\
\text { stage } \\
n=97\end{array}$ & $\begin{array}{l}\text { Two- } \\
\text { stage } \\
n=28\end{array}$ & $\begin{array}{l}\text { Clamping } \\
\geq 2 \text { min } \\
n=67\end{array}$ & $\begin{array}{l}\text { Clamping } \\
\leq 20 \mathrm{~s} \\
n=58\end{array}$ & \\
\hline $\begin{array}{l}\text { Nothing could have } \\
\text { been done better }\end{array}$ & 67 & 26 & 51 & 42 & 'There isn't anything that could have been done better' \\
\hline $\begin{array}{l}\text { Approach earlier/different } \\
\text { time }\end{array}$ & 4 & 5 & 3 & 6 & $\begin{array}{l}\text { 'I think you could approach patients in earlier stages of labour. I was } \\
\text { approached at the point when my contractions were quite strong and frequent } \\
\text { and it was quite hard for me to concentrate on the information about the trial' } \\
\text { 'The point when we were approached about it was a bit of a stressful moment, } \\
\text { it probably would have been better another time but it is hard to know when!' }\end{array}$ \\
\hline $\begin{array}{l}\text { Explain afterwards which } \\
\text { intervention they received }\end{array}$ & 4 & - & 3 & 1 & $\begin{array}{l}\text { 'During my section and after the doctors and nurse were at odds as to what } \\
\text { they needed to do. That worried me at the time, but everything happened so } \\
\text { quickly, I lost track of what happened, and it was never explained as to the } \\
\text { outcome, which group he was drawn in' } \\
\text { 'If I am honest I haven't been told anything about my Cord Trial so I don't know } \\
\text { how long they waited? It would be interesting to know' }\end{array}$ \\
\hline $\begin{array}{l}\text { Better staff } \\
\text { communication about } \\
\text { the trial }\end{array}$ & 3 & - & 2 & 1 & $\begin{array}{l}\text { 'It didn't seem to be handed to everyone that I was in the Cord Trial. I had to } \\
\text { keep telling people I was in the trial. I wanted delayed clamping' } \\
\text { 'Knowing if you were in the trial before you had the baby. Staff didn't know } \\
\text { when he came out if they could cut the cord or not, as there was a panic to find } \\
\text { the envelope' }\end{array}$ \\
\hline More information & 2 & 1 & 2 & 1 & $\begin{array}{l}\text { 'Maybe explain that if the cord was short, as it was in my case, the baby would } \\
\text { be kept on the bed and there was risk her temperature could drop as it did } \\
\text { with (baby's name)' } \\
\text { 'Perhaps you could make some literature available to mothers who feel they'd like } \\
\text { to read it, about delayed cord-clamping. If the mother is anxious at this point, } \\
\text { information given verbally only can cover her head?' }\end{array}$ \\
\hline No randomisation & 1 & 1 & 2 & - & $\begin{array}{l}\text { 'Been able to choose which side you were on, however understand by it was a } \\
\text { pick of a hat. So not a problem' }\end{array}$ \\
\hline Other suggestions & 2 & 1 & 1 & 2 & $\begin{array}{l}\text { 'To be prepared for short cords especially in case of early babies' } \\
\text { 'To be told at the birth how long it was going to be for, not afterwards' } \\
\text { 'Arrange times to go back and see a patient-don't turn up to the bed } \\
\text { unannounced! To be honest I was under so much stress with severe pre- } \\
\text { eclampsia for a second time and this trial just gave me more stress on top and } \\
\text { then it turned out not to even be worth it because we didn't get the right } \\
\text { envelope!' }\end{array}$ \\
\hline
\end{tabular}

'Please tell us if there was anything about the Cord Pilot Trial, or your experience of joining the trial that you think was particularly good'

Again, two thirds of respondents to the first questionnaire answered this question (122/186, 66\%) (64 deferred clamping, 58 immediate clamping). Women valued detailed information and clear explanations, which they felt helped them understand the trial $(n=47)$. Many women commented that they found the staff caring and friendly ( $n=21)$ using terms such as 'friendliness', 'supportive', and 'reassuring'. A few also commented that they felt no pressure from staff to participate in the trial $(n=6)$. Women thought there were benefits to participating in the trial; they thought that the health of their baby was better as a result of taking part (these comments predominantly relate to the deferred clamping arm) $(n=15)$, and they that thought the trial would help other babies and families $(n=15)$ (Table 4$)$.
For the second questionnaire at 1 year, 79/133 (59\%) respondents provided comments (53 deferred clamping, 26 immediate clamping). Again, the details provided were broadly similar to those on the first questionnaire. Women appreciated detailed information and clear explanations $(n=22)$, and commented on the caring and friendly staff $(n=20)$. They thought that there were benefits to being involved, for their baby $(n=5)$ and for others $(n=5)$. Women also wrote positively about the personable nature of the trial $(n=5)$, such as receiving a first birthday card for their baby. Some women felt that they had learnt new and interesting things from participating in the trial $(n=4)$ (Additional file 2).

\section{Discussion}

Results of this questionnaire study provide insight into women's experiences of participating in the Cord Pilot 
Table 4 For the first questionnaire, summary of responses about what was good about the trial

\begin{tabular}{|c|c|c|c|c|c|}
\hline & \multicolumn{2}{|c|}{$\begin{array}{l}\text { Consent } \\
\text { pathway }\end{array}$} & \multicolumn{2}{|c|}{ Allocated group } & \multirow[t]{2}{*}{ Sample of comments } \\
\hline & $\begin{array}{l}\text { Usual } \\
\text { one- } \\
\text { stage } \\
n= \\
94\end{array}$ & $\begin{array}{l}\text { Two- } \\
\text { stage } \\
n= \\
28\end{array}$ & $\begin{array}{l}\text { Clamping } \\
\geq 2 \min \\
n=64\end{array}$ & $\begin{array}{l}\text { Clamping } \\
\leq 20 \text { s } \\
n=58\end{array}$ & \\
\hline $\begin{array}{l}\text { Good } \\
\text { information } \\
\text { and } \\
\text { explanation }\end{array}$ & 36 & 11 & 28 & 19 & $\begin{array}{l}\text { 'Everything was explained at length so I personally knew exactly what was } \\
\text { happening and how things went after the cord was clamped' } \\
\text { 'The way the information was given by friendly inspiring staff. The level of detail and } \\
\text { thorough research into me as an individual regarding me being an eligible and safe candidate' } \\
\text { 'The information that was given was explained exceptionally well' }\end{array}$ \\
\hline $\begin{array}{l}\text { Caring and } \\
\text { friendly staff }\end{array}$ & 16 & 5 & 12 & 9 & $\begin{array}{l}\text { The staff who explained the project were very friendly and took an interest in our family } \\
\text { whilst we were waiting for our baby to be born' } \\
\text { 'The friendliness of the staff involved' } \\
\text { '(name of member of staff) who has been lovely and supportive' } \\
\text { The reassurance given that mine and my son's health and well-being were the most important thing' }\end{array}$ \\
\hline $\begin{array}{l}\text { Benefit to } \\
\text { baby }\end{array}$ & 10 & 5 & 12 & 3 & $\begin{array}{l}\text { 'I truly feel that keeping my baby attached to me made a huge difference to his health. He did } \\
\text { not require too much help directly after birth and has so far done really well' } \\
\text { I felt that the trial helped my daughter get stronger everyday by allowing her the extra } 30 \% \text { of } \\
\text { blood. I would definitely participate again' } \\
\text { 'My experience of joining the Cord Pilot Trial was an adventure because it could of helped my } \\
\text { son and it did' }\end{array}$ \\
\hline $\begin{array}{l}\text { Benefit to } \\
\text { others }\end{array}$ & 12 & 3 & 9 & 6 & $\begin{array}{l}\text { 'Trials like this are great and are for the health and well-being of babies. It is nice to have taken } \\
\text { part in trials that will better the care for babies' } \\
\text { 'The thought that it could be helping other babies and their families' } \\
\text { 'Being part of a trial that could help future premature babies was comforting at an emotional } \\
\text { time' }\end{array}$ \\
\hline $\begin{array}{l}\text { No pressure } \\
\text { from staff }\end{array}$ & 4 & 2 & 4 & 2 & $\begin{array}{l}\text { 'I didn't feel pressured to participate' } \\
\text { 'I had the time to decide if I wanted to participate' }\end{array}$ \\
\hline $\begin{array}{l}\text { See baby } \\
\text { for longer }\end{array}$ & 4 & - & 3 & 1 & $\begin{array}{l}\text { 'At the birth, seeing it in front of you, you understand why it is so important for mother and baby to } \\
\text { be close together-bond not broken at birth' } \\
\text { 'In addition to my previous response the cord trial allowed us to observe our baby straight after } \\
\text { birth and be reassured he was able to cope well outside the womb' }\end{array}$ \\
\hline Other & 9 & 4 & 9 & 4 & $\begin{array}{l}\text { The good thing is I had a chance to join the trial and I got the knowledge from that trial. If I didn't } \\
\text { join I was not going to know anything about it' } \\
\text { 'Joining the trial was easy. It didn't take a lot of time and I didn't even feel like we was part of } \\
\text { trial it felt very natural' } \\
\text { 'Being able to get a dvd of the baby's first moments of life' }\end{array}$ \\
\hline
\end{tabular}

Trial. The response rate was higher for the first questionnaire, than for the second at 1 year; and at 1 year the response was much higher for those allocated deferred clamping (66\% and 43\%, respectively). Responses to the questions were similar at the two times frames however. Overall, women were positive about the trial and their participation, and only a few said that they would not participate again. There were no clear differences in response about participating again according to any pre-specified factors, including the consent pathway, except that a greater proportion of women allocated deferred clamping indicated that they would definitely participate again than those allocated immediate clamping. The main reasons that women gave for their positive response were altruistic (benefits to others, importance of research), benefits to the baby, and no risk to the baby. These are in line with what has been reported for other studies recruiting women into trials during pregnancy $[15,16]$. Things women said they liked about the trial included detailed information and clear explanations of the study, and the caring and friendly staff. A greater proportion of women allocated deferred clamping made comments indicating that they thought that the health of their baby was better as a result of joining the trial.

For this trial, women were approached and invited to participate at a difficult time as they already knew their baby was likely to be born too early; and for some, birth was imminent. Therefore, it is unsurprising that some women said that they would prefer this approach to have been earlier and that they would have liked more information, albeit recognising that it can be hard to know when. This comment was made by women recruited using both the usual consent pathway and the two-stage pathway. Other studies have also reported that women would like information earlier. For example, one study exploring women's experiences of an intrapartum trial in an emergency setting found that whilst women recognised that information provided during pregnancy may 
not be personally salient they thought that women should be given the choice whether or not to engage with the material [17]. However, in comparison, staff were concerned that giving information to all women would be an ineffective use of time and resources, and potentially distressing to many women to whom it would not be relevant [17]. Furthermore, on the second questionnaire at 1 year, some women wrote that the first questionnaire could have been timed better when it was less hectic, and that they would have liked to have received more updates about the progress and results of the trial. In a qualitative study exploring parents' reactions to trial results, parents said that feedback was important to them because it provided further information and clarity, helped them to remember an emotional time, and acknowledged their important contribution to medical research [18]. Therefore, for a trial such as the Cord Pilot Trial where the follow-up continues long after the intervention has been completed, keeping participants up to date on trial progress and when they might expect to know the results of the trial, is particularly important. Consistent with previous research $[19,20]$, responses from several women suggested a misunderstanding of the randomisation process; for example, saying '... it (being in the trial) turned out not to even be worth it because we didn't get the right envelope'.

Feedback from women who completed these two questionnaires is reassuring that the study was appropriately designed and relevant to those who participated. This is reflected in the higher than anticipated recruitment and good retention of participants, both of which are likely to be improved by well-designed studies integrated into existing health services that minimise inconvenience to participants [21, 22]. Nevertheless, women's responses suggest issues for researchers to consider when planning future similar studies. For example, ways in which information about the trial might be made available earlier; providing additional information about the trial and/or the background condition that is available for those women who wish to access it; and providing more updates about the trial to participants.

A strength of this study is that we received responses from a high proportion of participants in the trial. Using three questions added to a follow-up questionnaire is simple, cost-effective, and time-efficient. Although the traditional method for assessing participants' views is in-depth qualitative interviews, the responses to the questions used in our study are comparable with responses from studies using qualitative interviews [23]. Limitations of our study are that we do not know whether women who did not complete the questionnaire had a different experience of the Cord Pilot Trial. Also, women who were offered participation but declined or were not recruited for other reasons may have had different experiences and views. The experiences reported in this study may not be applicable to all parents who enrol their preterm baby into a clinical trial. Our results are based on a single trial, and other factors may be more or less important in trials with different risk and benefit profiles.

\section{Conclusions}

Overall, women were positive about their experiences of participating in the Cord Pilot Trial, with only a small number negative about their participation. Women cited the importance of research, the benefits for their baby and benefits to others as reasons for participating. Women were positive about the level of information and explanations and the friendly and caring staff in the trial. Nevertheless, women had suggestions for how to improve the study. For example, some women would like to have received more information about the trial earlier in labour or during pregnancy; others would have liked more updates about progress. Some of the feedback also reflects misunderstanding about randomisation, a common finding in similar studies, suggesting that research is needed on how best to communicate this with potential trial participants. Responses also highlight the importance of communicating trial results to participants. This study demonstrates the value of simple, low-cost questionnaires to assess participants' views of being in a randomised trial.

\section{Additional files}

Additional file 1: Summary of free-text responses to explain response to 'if time suddenly went backwards, and you had to do it all over again, would you agree to participate in the Cord Pilot Trial?'. (DOCX 38 kb)

Additional file 2: Summary of free-text responses to the two experience questions on the second questionnaire at 1 year. (DOCX $30 \mathrm{~kb}$ )

\section{Acknowledgements}

The authors thank all the women who participated in this trial, and their families, and to the clinical and research staff at the sites.

\section{Funding}

This paper presents work funded by the National Institute for Health Research (NIHR) under its Programme Grants for Applied Research funding scheme (RPPG-0609-10107). The views expressed are those of the authors and not necessarily those of the NHS, the NIHR or the Department of Health and Social Care. The funder had no role in study design, conduct, analysis or reporting.

\section{Availability of data and materials}

The datasets used and analysed during the current study are available from the corresponding author/Nottingham Clinical Trials Unit on reasonable request.

\section{Authors' contributions}

LD was the chief investigator of the Cord Pilot Trial and conceived the idea. $L A B$ was the trial manager of the Cord Pilot Trial and EJM the senior trial manager. $L B$ analysed the quantitative data from the questionnaires and $A S$ analysed the free-text responses (with input from SA). LB, LD, and AS drafted the manuscript. LD and SA designed the study.. All authors contributed to the interpretation of the results and revising the manuscript for important intellectual content. All authors read and approved the final manuscript. 


\section{Ethics approval and consent to participate}

Approval for this study was granted by the Nottingham 2 Research Ethics Committee (NRES reference 12/EM/0283). All participants gave written informed consent or oral assent prior to randomisation. Written consent was gained for participants giving oral assent prior to sending/giving out followup questionnaires.

\section{Consent for publication}

Not applicable.

\section{Competing interests}

The authors declare that they have no competing interests.

\section{Publisher's Note}

Springer Nature remains neutral with regard to jurisdictional claims in published maps and institutional affiliations.

\section{Author details}

${ }^{1}$ Nottingham Clinical Trials Unit, University of Nottingham, Nottingham NG7 2UH, UK. ${ }^{2}$ School of Health Sciences, University of Brighton, Falmer BN1 9PH, UK. ${ }^{3}$ Centre for Maternal and Child Health Research, School of Health Sciences, City University London, London EC1V OHB, UK.

Received: 21 September 2018 Accepted: 25 March 2019 Published online: 16 April 2019

\section{References}

1. Pushpa-Rajah A, Bradshaw L, Dorling J, Gyte G, Mitchell E, Thornton J, Duley $L$, on behalf of the Cord Pilot Trial Collaborative Group. Cord Pilot Ttrial immediate versus deferred cord clamping for very preterm birth (before 32 weeks' gestation): study protocol for a randomized controlled trial. Trials. 2014;15(1):258.

2. Bradshaw LE, Pushpa-Rajah A, Dorling J, Mitchell EJ, Duley L. Cord Pilot Trial: update to randomised trial protocol. Trials. 2015;16(1):1-3.

3. Duley L, Dorling J, Pushpa-Rajah A, Oddie SJ, Yoxall CW, Schoonakker B, Bradshaw L, Mitchell EJ, Fawke JA, Cord Pilot Trial Collaborative Group. Randomised trial of cord clamping and initial stabilisation at very preterm birth. Arch Dis Child Fetal Neonatal Ed. 2018;103(1):F6-F14.

4. Sawyer A, Ayers S, Bertullies S, Thomas M, Weeks AD, Yoxall CW, Duley L. Providing immediate neonatal care and resuscitation at birth beside the mother: parents' views, a qualitative study. BMJ Open. 2015;5(9):e008495

5. Yoxall CW, Ayers S, Sawyer A, Bertullies S, Thomas M, Weeks A, Duley L. Providing immediate neonatal care and resuscitation at birth beside the mother: clinicians' views, a qualitative study. BMJ Open. 2015;5(9):e008494.

6. Chhoa CY, Sawyer A, Ayers S, Pushpa-Rajah A, Duley L. Clinicians' views and experiences of offering two alternative consent pathways for participation in a preterm intrapartum trial: a qualitative study. Trials. 2017;18(1):196.

7. Sawyer A, Chhoa C, Ayers S, Pushpa-Rajah A, Duley L. Women's views and experiences of two alternative consent pathways for participation in a preterm intrapartum trial: a qualitative study. Trials. 2017:18(1):422.

8. Mohanna K. Informed consent. Research in pregnancy brings special considerations. BMJ. 1997;315(7102):249-50.

9. Wilman E, Megone C, Oliver S, Duley L, Gyte G, Wright J. The ethical issues regarding consent to clinical trials with pre-term or sick neonates: a systematic review (framework synthesis) of the empirical research. Trials. 2015;16:502.

10. Duley L, Pushpa-Rajah A, Bradshaw L, Dorling J, Mitchell E. When an external pilot is successful, should it be possible to transform it into an internal pilot by continuing recruitment into the full trial is ready? A case study of the Cord Pilot Trial. Trials. 2015;16(2):P15.

11. Smyth RMD, Duley L, Jacoby A, Elbourne D. Women's experiences of participating in the Magpie Trial: a postal survey in the United Kingdom. Birth. 2009;36(3):220-9.

12. Bradshaw L, Sawyer A, Armstrong-Buisseret L, Mitchell E, Ayers S, Duley L. Cord Pilot Trial, comparing alternative policies for timing of cord clamping before 32 weeks gestation: follow-up for women up to one year. BMC Pregnancy Childbirth. 2019;19(1):78.

13. Zigmond AS, Snaith RP. The Hospital Anxiety and Depression Scale. Acta Psychiatr Scand. 1983;67(6):361-70.

14. Meyer DZ, Avery LM. Excel as a qualitative data analysis tool. Field Methods. 2009;21(1):91-112.
15. Sammons HM, Atkinson M, Choonara I, Stephenson T. What motivates British parents to consent for research? A questionnaire study. BMC Pediatr. 2007;7:12

16. Ayers S, Sawyer A, Düring C, Rabe H. Parents report positive experiences about enrolling babies in a cord-related clinical trial before birth. Acta Paediatr. 2015;104(4):e164-70.

17. Lawton J, Snowdon C, Morrow S, Norman JE, Denison FC, Hallowell N. Recruiting and consenting into a peripartum trial in an emergency setting: a qualitative study of the experiences and views of women and healthcare professionals. Trials. 2016;17(1):195.

18. Snowdon C, Garcia J, Elbourne D. Reactions of participants to the results of a randomised controlled trial: exploratory study. BMJ. 1998;317(7150):21-6.

19. Edwards SJ, Lilford RJ, Braunholtz DA, Jackson JC, Hewison J, Thornton J. Ethical issues in the design and conduct of randomised controlled trials. Health Technol Assess. 1998:2(15):i-vi 1-132.

20. Featherstone K, Donovan JL. 'Why don't they just tell me straight, why allocate it?' The struggle to make sense of participating in a randomised controlled trial. Soc Sci Med. 2002;55(5):709-19.

21. van der Zande ISE, van der Graaf R, Hooft L, van Delden JJM. Facilitators and barriers to pregnant women's participation in research: a systematic review. Women Birth. 2018;31(5):350-61.

22. Meshaka R, Jeffares S, Sadrudin F, Huisman N, Saravanan P. Why do pregnant women participate in research? A patient participation investigation using Q-Methodology. Health Expect. 2017;20(2):188-97.

23. Cartwright $\mathrm{K}$, Mahoney L, Ayers S, Rabe H. Parents' perceptions of their infants' participation in randomized controlled trials. J Obstet Gynecol Neonatal Nurs. 2011:40(5):555-65.

\section{Ready to submit your research? Choose BMC and benefit from:}

- fast, convenient online submission

- thorough peer review by experienced researchers in your field

- rapid publication on acceptance

- support for research data, including large and complex data types

- gold Open Access which fosters wider collaboration and increased citations

- maximum visibility for your research: over $100 \mathrm{M}$ website views per year

At BMC, research is always in progress.

Learn more biomedcentral.com/submissions 